\title{
Sudden oak death spurs massive team effort
}

W.R. GOMES

Vice President

Agriculture and Natural Resources
"California agriculture" has myriad meanings: it is food production and processing of more than 250 crops; it is cultivation of foods with high nutritional content; it is urban horticulture. Because agriculture is inseparable from the natural environment, it is also the study of ecosystems, such as conifer and oak forests.

Threats to California's agricultural and natural abundance arise continually. Scientists estimate that every 60 days a new exotic pest threatens the state's agricultural, natural and urban environments.

New pests and plant diseases can be profound and baffling. One recent example is the emergence of sudden oak death, which has already claimed tens of thousands of oaks in seven coastal counties. This devastation has stimulated the involvement of every component of the Division of Agriculture and Natural Resources, from Cooperative Extension (CE) advisors to laboratory scientists. It has involved collaborations with state and federal agencies, and consultations with university scientists around the world.

The battle against sudden oak death began in 1995, when homeowners living near Mt. Tamalpais reported an unusual tanoak dieback. Marin County CE advisors were instrumental in characterizing the symptoms and progression of this mortality complex. Initial laboratory tests failed to reveal a single cause. Oak deaths spread throughout the North Bay. In 1998, the elevated mortality first appeared in coast live oak and California black oak. Monterey and Santa Cruz counties began to receive similar reports. CE advisors in affected counties developed educational programs for landowners and natural resource professionals.

By 1999, the levels of native tree losses exceeded any historical reports. A massive research and education effort was undertaken to find the source of the loss and to develop management recommendations. That year CE specialists with UC's Integrated Hardwood Range Management Program, backed by special Division funds, established a research team including faculty from the UC Berkeley and UC Davis campuses, and $C E$ specialists and advisors.

Today that UC research team is composed of 23 academics in plant pathology, entomology, natural resource monitoring, forest ecology, wildlife, fire management, silviculture and urban forestry. The UC Center for the Analysis and Monitoring of Forest and Environmental Resources (CAMFER), and the UC Center for Forestry have also become active participants in the research effort.

By spring of 2000, the USDA Forest Service joined the research effort, and contributed additional financial support to the research team. Shortly afterwards, UC Davis plant pa- thologists succeeded in culturing a previously unknown species of Phytophthora, which seemed to be the source of much of the unexplained mortality. UC Berkeley CE specialists in forest pathology began genetic investigations of this newly discovered organism. Based on the work of these two laboratories, scientists concluded that the organism causing the mortality was different from the 60 previously recognized species in the Phytophthora genus. National and international experts were brought in to broaden the evaluation.

Eventually, the same organism was determined to be present in rhododendrons in Santa Cruz County and Europe. Meanwhile, UC Berkeley's CAMFER faculty developed a Web based monitoring effort in which they systematically mapped the distribution of the elevated mortality. By linking maps and aerial imagery with laboratory detection efforts, CAMFER allows the public and various agencies to see where confirmed cases of the new Phytophthora were located.

With the disease organism identified, and public concern about dying oaks mounting, the state's Forest Pest Council, a standing committee of the State Board of Forestry, established a California Oak Mortality Task Force (COMTF). This task force included the UC research and extension scientists, as well as state, federal, county, and municipal agencies, and various private groups.

Current research is focused on establishing the source of this newly discovered organism, as well as its means of spread. In addition, management recommendations are being developed, to be tested with local cooperators. A risk analysis of the effects of the elevated mortality on wildfire, wildlife habitat, and urban waste disposal (of dead trees) is under development.

The breadth of response to sudden oak death illustrates the importance of maintaining not only a strong research capability, but a strong extension capability to deliver research results to those who need them. The local CE offices were the first to draw attention to sudden oak death. They helped ensure that scientists focused on this spreading malady and they transferred research results to the broad audience concerned with sustainable management of the state's oak woodlands. Effective communication with UC's partners in various public agencies and private groups was also facilitated by the newly formed COMTF.

This issue of California Agriculture presents news and research articles describing UC's most recent findings and management actions in response to sudden oak death. It is a story of university research and extension marshalled to a critical statewide need, and of close cooperation with government agencies to address that need. 